\title{
PENGARUH CITRA TOKO DAN ATMOSFER TOKO TERHADAP KEPUTUSAN PEMBELIAN KONSUMEN DI RAMAYANA DEPARTEMENT STORE - DEPOK
}

\author{
Dadan Sundara \\ Email : dadan.sundara@gmail.com \\ Program Studi Manajemen, Fakultas Ekonomi \\ Institut Bisnis dan Informatika (IBI) Kosgoro 1957
}

\begin{abstract}
This Research aims to clarify: how the influence of store image and store atmosperics on buying decision at Ramayana Store-Depok. The Research had used method of convenience sampling with 30 samples of consumers who were in store and analyzed by SPSS Software version 22. The Result of research showed as follow: (1) Variables of store image has no significant effect on buying decisions in Ramayana Depok. This was showed by the probability value $>0.05$; (2) Variables of store atmosperics has significant effect on buying decisions in Ramayana Depok. This was showed by the probability value < 0.05; (3) simultaneously variables of store image and the variables of store atmosperics were significant for buying decisions at Ramayana Store - Depok. Those were showed by test Fcalculate > F table (14.127 > 3.25) and sign $0.000<0.05$; (4) Consumer buying decisions are influenced by variables of store image and variables of store atmosperics up to $43.30 \%$ while $56.70 \%$ are influenced by other variables

Keywords: Store Image, Store Atmosperics, Buying Decision, Department Store
\end{abstract}

\section{PENDAHULUAN}

Indonesia adalah salah satu negara yang tercatat sebagai negara dengan penduduk yang terbesar ke empat di dunia, Indonesia (wordmeters, 28 April 2019), sesuai gambar di bawah ini:

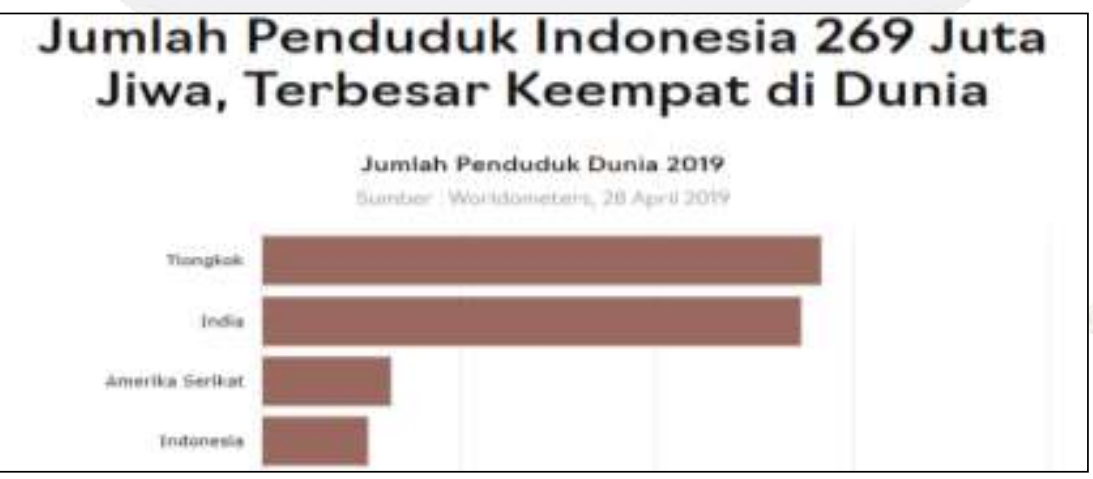

Gambar 1. Jumlah Penduduk Dunia

Sumber: Wordmeters, 28 April 2019 
Oleh sebab itu, Indonesia menjadi suatu lahan peluang yang menarik bagi pengusaha retail, baik pengusaha retai lokal maupun pengusaha retail dari luar negeri. Berbagai pengusaha retail berlomba untuk dapat berkembang di Indonesia seperti Carefour, Giant, Lotte Mark, Sogo, Ramayana, Matahari, AlfaMidi, Indomaret, Transmart.

Meskipun perekonomian Indonesia mengalami krisis ekonomi yang berkepanjangan dan kondisi politik tidak mendukung di tahun 1987-an hingga sekarang, tetapi usaha bisnis di bidang retail khususnya toko serba ada atau department store tetap bertahan bahkan dapat dikatakan bisa berkembang dan menjadi suatu usaha yang cukup menjanjikan. Berdasarkan data dari www.ceicdata.com, data pertumbuhan retail di Indonesia pada tahun 2011 sampai 2019 di bulan Agustus, rata-rata 9,8 \% per tahun. Bahkan menurut wakil ketua asosiasi pengusaha ritel Indonesia (Aprindo) Tutum Rahanta mengatakan bahwa mereka tetap optimistis dan akan melanjutkan pertumbuhan $10 \%$ tahun ini dimana tetap hati-hati, sehingga pertumbuhan $10 \%$ kali ini lebih konservatif. Menurut Tutum kembali, bahwa kinerja industri ritel modern di tahun 2019 ini akan dipengaruhi oleh tren belanja konsumen yang cenderung wait and see seiring mengikuti tahun politik. Disisi lain, para peritel masih harus menghadapi tekanan-tekanan akibat persaingan yang ketat dengan para pelaku perdagangan elektronik" (https://ekonomi.bisnis.com/)

Pada kondisi sekarang ini banyak di temukan beberapa department store yang di bangun (baik itu department store baru atau pembukaan cabang-cabang department store) untuk mengikuti keinginan konsumen di dalam memenuhi kebutuhan pokok, tentunya adanya suatu sebab akibat tumbuhnya toko serba ada atau department store. Ada alasan dari sebab akibat ini yaitu banyak produk yang beraneka ragam yang di tawarkan dan semakin selektifnya konsumen terhadap barang. Ditambah dari hasil penelitian oleh Nelsen (www.cnnindonesia.com) yang menyatakan bahwa adanya kelesunya penjualan barang konsumsi yang disebabkan oleh melemahnya daya beli kelompok menengah ke bawah dan masyarakat 
yang semakin selektif saat berbelanja yang secara langsung mempengaruh atas keputusan pembelian konsumen

Keputusan pembelian belanja juga menjadi suatu pertimbangan oleh perusahaan-perusahaan retail di Indonesia di dalam meningkatkan volume penjualannya. Dimana salah satunya adalah PT. Ramayana Lestari Sentosa Tbk yang bergerak di usaha retail untuk kalangan menengah ke bawah. Biasanya pelanggan menengah ke bawah sangat sensitif terhadap jenis produk dan harga serta pelayanan sehingga bagi perusahaan retail harus hati-hati di dalam mengambil keputusan untuk ketiga hal tersebut.

Beberapa penelitian yang sudah dilakukan atas lingkungan toko yaitu oleh Septian Vety Tunjungsari dan kawan-kawan (2016) menunjukkan suasana toko (store atmosphere) berpengaruh positif dan signifikan. Penelitian oleh Muhammad Maftukhan (2017) Menunjukkan lingkungan toko berpengaruh secara signifikan terhadap keputusan pembelian. Penelitian oleh Luis Krumpellman (2018) menunjukkan pada lingkungan toko berpengaruh secara positif dan signifikan atas perilaku pembeli dan kepuasan pelanggan. Penelitian oleh M. Rifa'l (2018) menunjukkan citra toko berpengaruh terhadap beli konsumen.

Permasalahan adalah apakah perusahaan retail seperti Ramayana hanya mengandalkan harga barang murah dan strategi pemasaran berupa promosi yang gencar saja Masih terdapat faktor-faktor lain yang harus dipertimbangkan seperti citra toko dan atmosfer toko yang dapat memberikan sesuatu kenyamanan dan keamanan bagi para pengunjung yang datang ke sebuah retail serta mampu merangsang mereka untuk dapat menghabiskan waktu dan berbelanja di toko tersebut.

\section{TINJAUAN PUSTAKA}

\subsection{Pemasaran Retail}

Menurut Kotler (2009:140) retailing adalah semua aktivitas dalam menjual barang atau jasa langsung ke konsumen akhir untuk kebutuhan pribadi dan non bisnis. Retail menurut Hendri Ma'ruf (Kholid, 2020) yaitu, 
"kegiatan usaha menjual barang atau jasa kepada perorangan untuk keperluan diri sendiri, keluarga, atau rumah tangga".

Menurut pendapat Ma'ruf (2005:9) dikatakan bahwa sikap perusahaan retail sebagai penjual barang atau jasa terhadap pembelinya dapat dilihat dari sesuai yang menjadi dasar (berpikir, bertindak dan lainya) dan sasaran mereka. Sebagian dari mereka berpangkal tolak atau berangkat dari dirinya sendiri dengan sasaran mencapai laba melalui penjualan setinggitingginya. Untuk jelasnya dapat dilihat gambar di bawah ini:

\begin{tabular}{|cccc|}
\hline $\begin{array}{c}\text { Pangkal } \\
\text { Tolak }\end{array}$ & Fokus & Cara & Sasaran \\
\hline $\begin{array}{l}\text { TARGET } \\
\text { MARKET }\end{array}$ & KEBUTUHAN & UPAYA PEMASARAN & PENCAPAIAN LABA MELLLUI \\
\hline
\end{tabular}

\section{Gambar 2. Sikap Terhadap Pasar yang Berorientasi Pemasaran}

Sumber: Hendri Ma'ruf, Pemasaran Ritel, 2005

Dari gambar di atas menggambarkan perusahaan retail menentukan dahulu market yang berisi kumpulan pelanggan dengan sasaran samasama senang yaitu perusahaan mendapatkan laba dan pelanggan mendapatkan kepuasan dalam belanja. Jika 4P, 4C dan unsur-unsur dipadukan dalam bauran pemasaran retail maka terlihat gambaran pemasaran retail sebagai berikut:

\begin{tabular}{lll}
\hline \multicolumn{1}{c}{ EMPAT P } & \multicolumn{1}{c}{ EMPAT C } & UNSUR-UNSUR DALAM PEMASARAN RETAIL \\
\hline Product (Produk) & Customer Solution (Solusi Pelanggan) & Merchandise \\
Price (Harga) & Customer Cost (Biaya Pelanggan) & Price \\
Place (tempat) & Convenience (Kenyamanan) & Location, Space, Atmosfer, Retail Service \\
Promotion (Promosi) & Communication (Komunikasi) & Promotion Mix (Bauran Unsur-unsur Pemasaran
\end{tabular}

Gambar 3. Hubungan 4P, 4C dengan Unsur-unsur Pemasaran Retail Sumber: Hendri Ma'ruf, Pemasaran Ritel, 2005

\subsection{Lingkungan Toko (Store Enviroment)}

Lingkungan toko menjadi salah satu strategi pemasaran retail di dalam meningkatkan penjualan selain menjalan strategi bauran pemasaran. 
Lingkungan toko yang baik adalah lingkungan yang dapat memberikan sesuatu kenyamanan dan keamanan bagi para pengunjung yang datang ke sebuah retail serta mampu merangsang mereka untuk dapat menghabiskan waktu dan berbelanja. Lingkungan toko menurut Engel (Maftukhan, 2017), terdiri atas beberapa elemen seperti: tata ruang toko, ruang lorong, penempatan, pencahayaan, warna, temperatur, aroma dan musik. Demikian halnya Baker (Maftukhan, 2017), menyatakan Lingkungan toko terdiri dari: faktor desain, faktor ambient dan faktor sosial.

Lingkungan toko mempengaruhi keputusan pembelian konsumen yang diperkuat penelitian oleh Kurt Salomon Associates (Cut Devi, 2020) menyatakan ada 10 yang membuat konsumen gagal membeli ataupun meninggalkan warung tanpa transaksi yaitu: produk yang dijual tidak sedang musim, tata letak produk dalam toko tidak nyaman, tidak menemukan nilai, situasi toko kurang nyaman, harga lebih tinggi dari yang lain, sulit keluar masuk toko, tidak memiliki karyawan yang mampu menjelaskan info produk, toko kehabisan stok barang, tidak menemukan ukuran yang sesuai, gaya atau bentuk yang kurang menarik. Sedangkan penelitian Dale M, Lewinson (Bilson Simamora, 2003) menyatakan bahwa 70 - 80 \% keputusan pembelian konsumen dilakukan di dalam toko. Lingkungan toko dapat dibagi menjadi 3 (tiga) elemen penting yaitu: citra toko (store image), atmosfer toko (store atmospherics) dan pertunjukan toko (store theatrics)

\section{1) Citra Toko (Store Image)}

Berdasarkan Citra toko menurut Christina Widya Utami (2010) adalah konseptualisasi lokal yang diharapkan mampu berhubungan dengan aktivitas belanja pada sebuah toko tertentu. Citra toko adalah salah satu bagian yang terpenting bagi retailer untuk menarik dan memenuhi kepuasan konsumen. Konsumen dapat menilai toko berdasarkan pengalaman-pengalaman mereka saat berbelanja pada toko tersebut. Citra adalah suatu bayangan atau gambaran yang ada dibenak 
seseorang yang timbul karena adanya emosi dan reaksi terhadap lingkungan yang ada di sekitarnya.

2) Atmosfer Toko (Store Atmosperics)

Atmosfer toko adalah keseluruhan efek emosional yang diciptakan oleh atribut toko melalui, pertama sight appeal yaitu efek emosional melalui penglihatan konsumen di dalam toko. Kedua, sound appeal yaitu efek emosional melalui pendengaran konsumen di dalam toko. Ketiga, scent appeal yaitu efek emosional konsumen melalui aroma di dalam toko yang meliputi aroma ruang toko dan empat, touch appeal adalah bagaimana konsumen melakukan inspeksi pada produk yang dilihat.

3) Pertunjukan Toko (Store Teatrics)

Pertunjukan toko merupakan suatu acara pameran atau pagelaran produk di toko yang memicu konsumen untuk membeli produk yang dipamerkan. Pertunjukan toko dapat merupakan alat yang ampuh bagi retailer untuk mendapatkan competitive advantage yang mampu membedakan antara satu retailer dengan yang lainnya.

\subsection{Keputusan Pembelian}

Menurut Peter dan Olson (Venty Septian T, Achamd Fauzi, M Kholid Mawardi) keputusan pembelian adalah suatu proses integritas yang dilakukan untuk mengombinasikan pengetahuan guna mengevaluasi dua atau lebih suatu alternatif dan akan memilih satu diantaranya. Sehingga keputusan pembelian diartikan sebagai proses pemilihan konsumen terhadap dua atau lebih suatu alternatif pilihan yang kemudian dipilih salah satu alternatif yang menjadi kebutuhan konsumen.

Keputusan Pembelian Menurut Kotler (2009: 184) dikatakan bahwa proses suatu keputusan pembelian terdiri dari lima tahap, yaitu:

1) Pengenalan Kebutuhan

Proses pembelian dimulai ketika pembeli menyadari masalah atau kebutuhan dipicu oleh rangsangan internal atau eksternal. 
Pemasar perlu mengidentifikasi keadaan yang memicu kebutuhan tertentu dengan mengumpulkan informasi-informasi dari sejumlah konsumen. Lalu mereka mengembangkan suatu strategi pemasaran yang dapat memicu minat konsumen untuk melakukan pembelian.

2) Pencarian Informasi

Saat konsumen telah menyadari adanya kebutuhan atau masalahnya, maka konsumen mencari solusi di dalam memuaskan kebutuhannya tersebut melalui suatu pencarian informasi.

3) Evaluasi Alternatif

Ada beberapa konsep yang membantu memahami proses evaluasi konsumen. Pertama, suatu konsumen berusaha memuaskan kebutuhan. Kedua, konsumen mencari manfaat tertentu dari solusi produk yang dia inginkan. Ketiga, suatu konsumen akan memandang masing-masing produk yang ada sebagai sekumpulan atribut dengan berbagai kemampuan untuk menghantarkan adanya manfaat yang diperlukan untuk memuaskan kebutuhan konsumen.

4) Keputusan Pembelian

Selama proses evaluasi, konsumen akan membentuk preferensi di antara alternatif pilihan yang ada. Apabila suatu produk/layanan dapat memenuhi kebutuhan, konsumen mengambil tindakan untuk membeli produk/layanan tersebut.

5) Perilaku Pasca Pembelian

Setelah pembelian yang dilakukan, ada kemungkinan konsumen mengalami konflik dikarenakan melihat fitur mengkhawatirkan tertentu atau mendengar hal-hal menyenangkan mengenai merek lain dan waspada terhadap adanya informasi yang mendukung keputusannya. Sehingga pemasar harus mengamati kepuasan pasca pembelian, tindakan pasca pembelian, dan penggunaan produk pasca pembelian. 


\section{METODE PENELITIAN}

\subsection{Tempat dan waktu Penelitian}

Tempat penelitian dilakukan di Ramayana Depok di alamat Jl. Margonda Raya - Depok. Adapun waktu penelitian dilakukan mulai bulan Agustus - September 2019.

\subsection{Metode Pengumpulan Data}

Metode dilakukan dalam penelitian adalah metode wawancara dan metode kuesioner.

\subsection{Sumber Data}

Data-data yang digunakan adalah dari data primer yaitu data yang didapat secara langsung dengan menyebar kuesioner kepada para pembeli di Ramayana Depok dan data Sekunder yaitu data pendukung berupa studi perpustakaan di beberapa sumber data seperti di PT. Ramayana Lestari Sentosa Tbk, Perhimpunan Retail Indonesia, artikel dan jurnal retail.

\subsection{Model Penelitian}

Menurut Bilson Simamora (2003:167), Dimana Terdapat 3 (tiga) elemen Lingkungan Toko yang mempengaruhi keputusan pembelian:

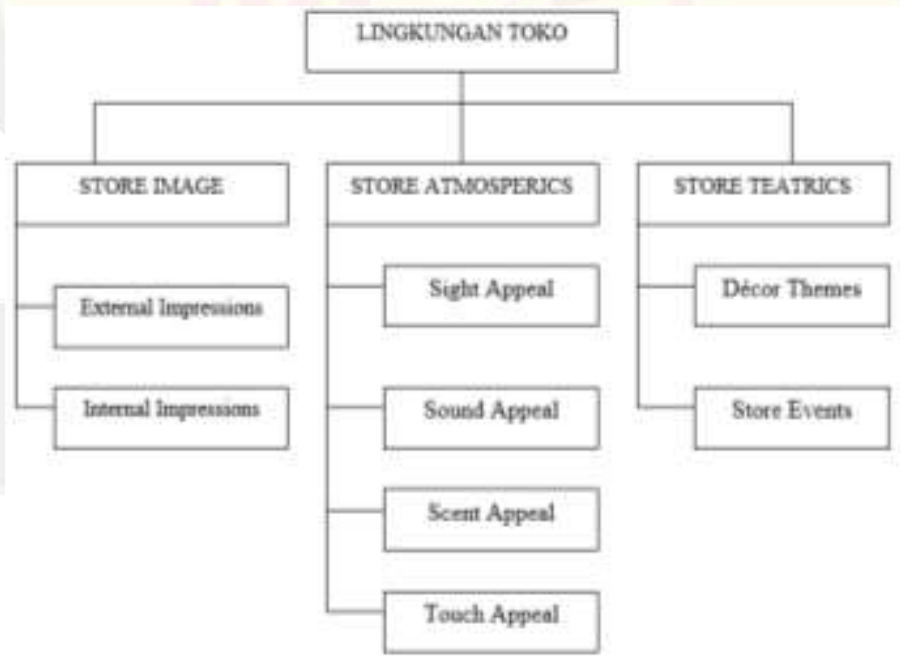

Gambar 4: Kerangka Pemikiran

Sumber : Bilson Simamora, 2003 
Dengan indikator-indikator sebagai berikut:

\begin{tabular}{|l||l|}
\hline \multicolumn{1}{|l||}{ CITRA TOKO (STORE IMAGE) } & \multicolumn{1}{c|}{ ATMOSFER TOKO } \\
\hline \hline External Impressions: & Sight Appeal: \\
- Lokasi toko & - Ukuran departemen toko \\
- Desain toko & - Dekorasi departemen toko \\
- Penempatan logo & Sound Appeal: \\
- Pintu masuk toko & - Musik toko \\
- Etalase muka toko & - Informasi di toko \\
Internal Impressions: & Scent Appeal: \\
- Warna toko & - Aroma ruang toko \\
- Bentuk toko & Touch Appeal: \\
- Ukuran toko & - Tata ruangan toko \\
- Penempatan urutan departemen & - Letak pajangan toko \\
- Pengaturan lalu lintas pengunjung & - Pengaturan rak toko \\
- Kebersihan toko & - Display barang toko \\
- Pelayanan toko & - Pengaturan lampu toko \\
\hline - Keamanan toko &
\end{tabular}

\subsection{Kerangka Pemikiran}

Berdasarkan identifikasi masalah dan tujuan masalah di atas maka kerangkan pemikiran adalah sebagai berikut:

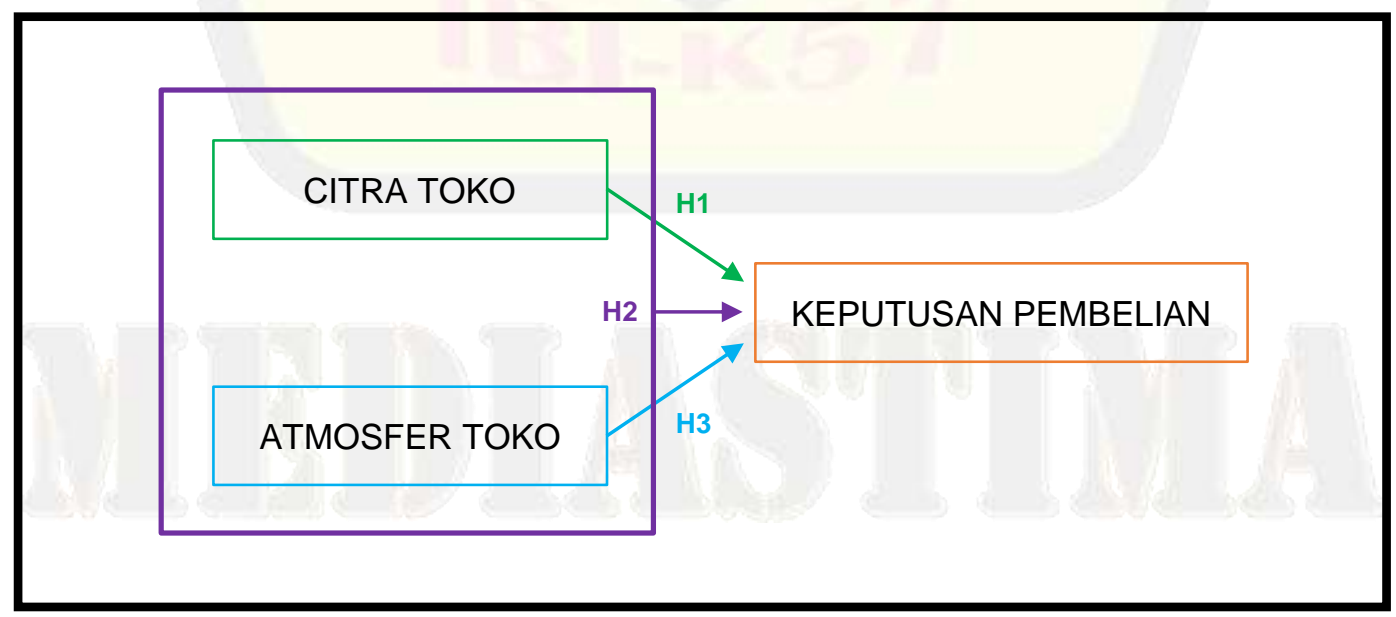

Gambar 5: Kerangka Pemikiran 
Berdasarkan kerangka pemikiran di atas maka hipotesis penelitian adalah:

H1: Diduga ada pengaruh positif dan signifikan citra toko dengan keputusan pembelian konsumen yang berbelanja di Ramayana Depok

H2: Diduga ada pengaruh positif dan signifikan atmosfer toko dengan keputusan pembelian konsumen yang berbelanja di Ramayana Depok

H3: Diduga ada pengaruh positif dan signifikan secara simultan citra toko dan atmosfer toko dengan keputusan pembelian konsumen yang berbelanja di Ramayana Depok

\subsection{Desain Penelitian}

Variabel bebas atau disebut independen variabel adalah X1, citra toko dan X2, atmosfer toko dan variabel terikat atau disebut dependen variabel adalah keputusan pembelian konsumen $(Y)$

\subsection{Metode Pengambilan Sampel}

Adapun metode pengambilan sampel yang dilakukan dalam penelitian adalah convenience sampling. Menurut Sugiarto (2003:38) convenience sampling yaitu sampel yang diambil berdasarkan ketersediaan elemen pada tempat dan waktu yang tepat. Sampel yang dilakukan adalah konsumen Ramayana yang sudah berbelanja di Ramayana Depok. Menurut Sugiyono (2009:217) bahwa untuk sampel yang layak adalah ukuran sampel yang paling minimum adalah 30 sampel sampai 500 sampel. Untuk memudahkan penelitian dengan pertimbangan waktu dan biaya maka sampel yang diambil adalah sebesar 40 sampel konsumen yang belanja di Ramayana Depok. 


\section{HASIL PENELITIAN DAN PEMBAHASAN}

\subsection{Uji Validitas dan Reliabilitas}

Tabel 1: Uji Validasi dan Uji Reliabilitas

\begin{tabular}{|c|c|c|c|c|}
\hline & $\begin{array}{l}\text { Scale Mean if } \\
\text { Item Deleted }\end{array}$ & $\begin{array}{l}\text { Scale Variance } \\
\text { if Item Deleted }\end{array}$ & $\begin{array}{l}\text { Corrected Item- } \\
\text { Total Correlation }\end{array}$ & $\begin{array}{c}\text { Cronbach's } \\
\text { Alpha if Item } \\
\text { Deleted }\end{array}$ \\
\hline $\mathrm{X} 1.1$ & 110,10 & 187,733 & .619 & .954 \\
\hline $\mathrm{X} 1.2$ & 110,42 & 183,533 & .625 & .954 \\
\hline$\times 1.3$ & 110,20 & 185,959 & .707 & .954 \\
\hline$\times 1.4$ & 110,47 & 183,230 & .576 & .955 \\
\hline$\times 1.5$ & 110,32 & 183,610 & .746 & .953 \\
\hline$\times 1.6$ & 110,55 & 185,177 & .638 & ,954 \\
\hline$\times 1.7$ & 110,65 & 184,800 & .628 & .954 \\
\hline $\mathrm{X} 1.8$ & 110,45 & 188,356 & .469 & .955 \\
\hline $\mathrm{X} 1.9$ & 110,52 & 181,128 & .768 & .953 \\
\hline$\times 1.10$ & 110,70 & 180,267 &, 701 & .953 \\
\hline$\times 1.11$ & 110,17 & 185,276 & .658 & .954 \\
\hline $\mathrm{X} 1.12$ & 110,27 & 183,435 & .754 & .953 \\
\hline$\times 2.1$ & 110,65 & 183,105 & .687 & .954 \\
\hline$\times 2.2$ & 110,60 & 186,041 & .578 & .955 \\
\hline$\times 2.3$ & 110,40 & 183,733 & .672 & .954 \\
\hline$\times 2.4$ & 110,42 & 187,174 & .600 & .954 \\
\hline$\times 2.5$ & 110,52 & 182,153 & .792 & .953 \\
\hline$\times 2.6$ & 110,45 & 184,972 & .693 & ,954 \\
\hline$\times 2.7$ & 110,42 & 180,763 & .793 & .953 \\
\hline$\times 2.8$ & 110,42 & 180,815 & .830 & .952 \\
\hline$\times 2.8$ & 110,42 & 186,763 & .520 & .955 \\
\hline Y.1 & 111,35 & 182,336 & .487 & .957 \\
\hline Ү.2 & 110,92 & 176,328 & .748 & .953 \\
\hline Ү.3 & 110,77 & 179,666 & .765 & .953 \\
\hline Ү.4 & 110,60 & 185,426 & .579 & .955 \\
\hline Y.5 & 110,75 & 183,577 & .576 & .955 \\
\hline Y. 6 & 110,57 & 184,558 &, 614 & ,954 \\
\hline
\end{tabular}

Sumber: Data SPSS

Berdasarkan tabel di atas dapat diambil kesimpulan bahwa data di atas valid dan reliabilitas karena memenuhi syarat sebagai berikut:

1) Data-data di kolom CITC (Corrected Item Total Correction) $>0,3$ maka dapat disimpulkan semua data adalah valid.

2) Data-data di kolom Cronchbach Alpha > 0,6 disimpulkan semua data adalah valid. 


\subsection{Uji Asumsi Klasik}

\section{A. Uji Normalitas Secara Grafik}

Normal P-P Plot of Regression Standardized Residual

Dependent Variable: Kep_Pembelian

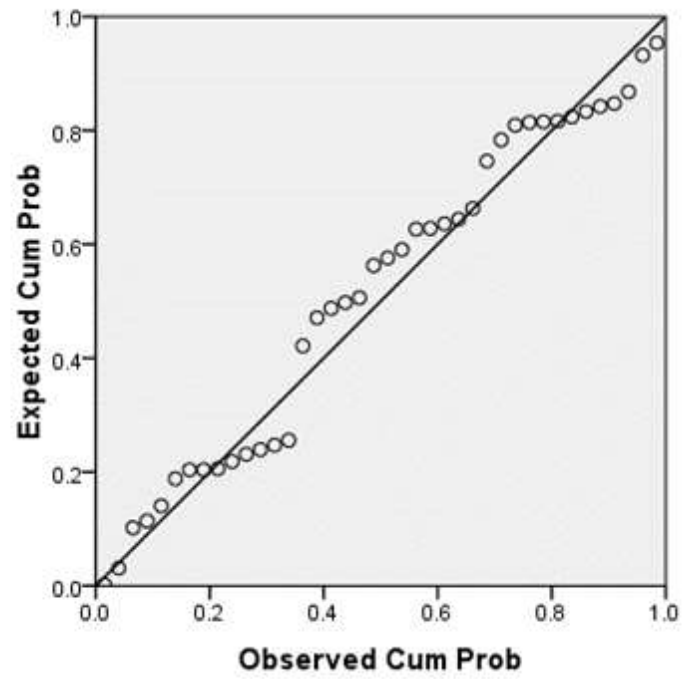

Gambar 6. Uji Normalitas Grafik

Sumber: Data SPSS

Gambar di atas menunjukkan Regression Standarized Residual tersebar di sekitar garis diagonal serta penyebaran mengikuti arah garis diagonal, disimpulkan bahwa data sudah memenuhi asumsi normalitas dan layak digunakan.

\section{B. Uji Multikolinieritas}

\section{Tabel 2: Uji Multikolinieritas}

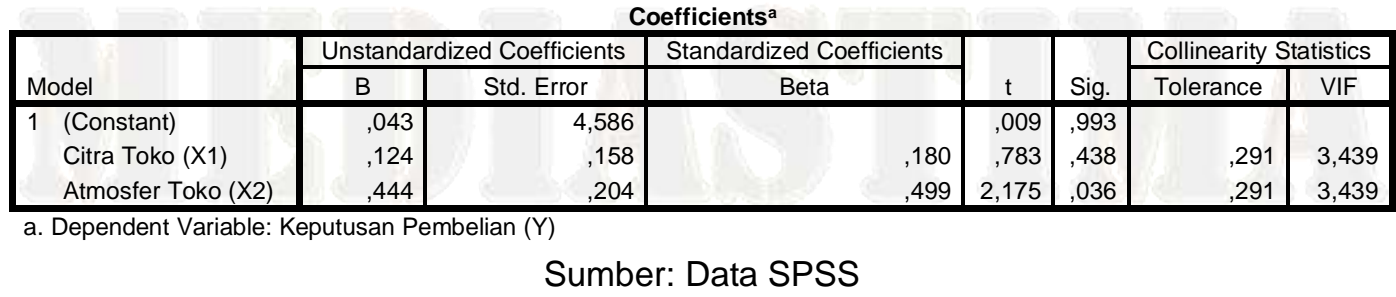

Dari tabel di atas menunjuk seluruh variabel independen yaitu citra toko dan atmosfer toko memiliki nilai toleransi $0,291>0,10$ atau nilai VIF 
sebesar $3.116<10$. Berdasarkan hal itu disimpulkan bahwa tidak ada mutikolonieritas dalam model regresi.

\section{Uji Heteroskedasitistas}

\section{Scatterplot}

\section{Dependent Variable: Kep_Pembelian}

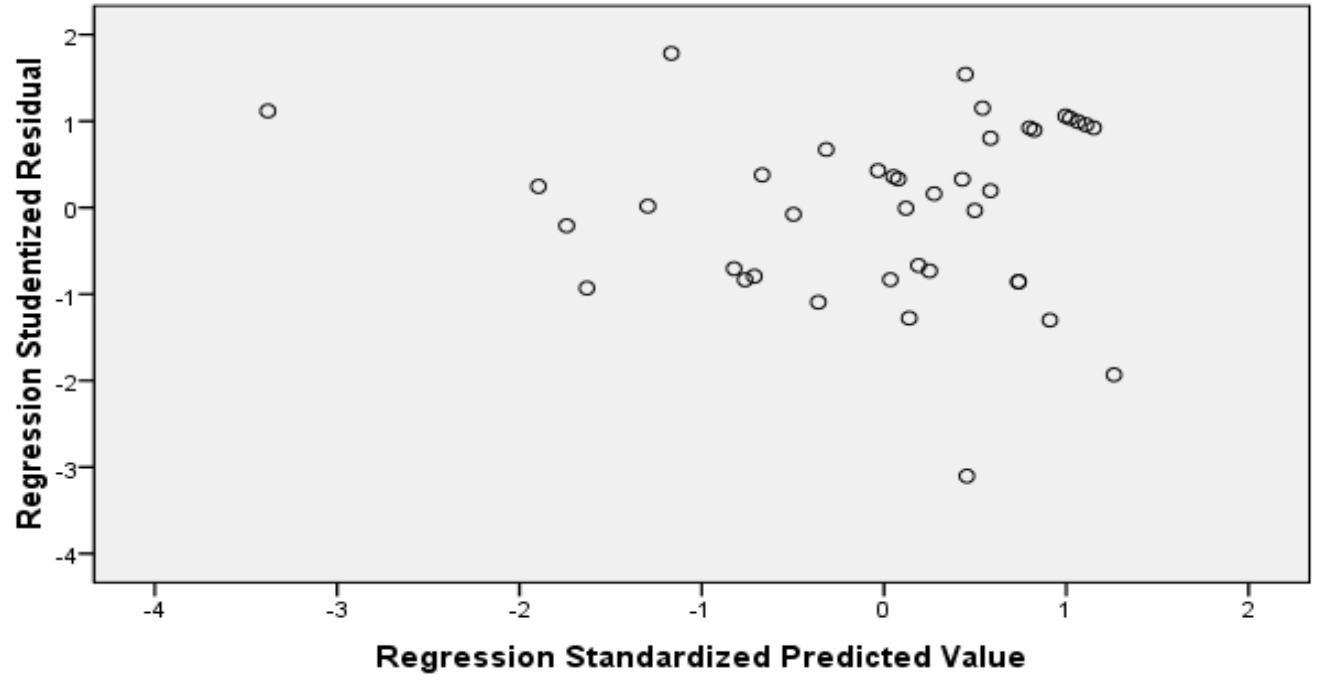

\section{Gambar 7: Uji Heteroskedasitistas}

Sumber: Data SPSS

Dari gambar di atas dapat diketahui bahwa tidak terjadi Heteroskedasitistas karena tidak terjadi pola yang jelas yang ditandai oleh titik-titik yang menyebar pada sumbu $\mathrm{Y}$, dapat disimpulkan uji Heteroskedasitistas terpenuhi.

\section{Uji Autokorelasi}

Tabel 3: Uji Autokorelasi

Model Summary

\begin{tabular}{|c|c|c|c|c|c|}
\hline Model & $\mathrm{R}$ & $\mathrm{R}$ Square & Adjusted R Square & Std. Error of the Estimate & Durbin-Watson \\
\hline
\end{tabular}

\begin{tabular}{|l|r|r|}
\hline 1 &, $658^{\mathrm{a}}$ &, 433 \\
\hline
\end{tabular}
402 3,378

a. Predictors: (Constant), Atmosfer Toko (X2), Citra Toko (X1)

b. Dependent Variable: Keputusan Pembelian (Y)

Sumber: Data SPSS 
Tabel di atas menunjukkan untuk Durbin-Watson (DW) sebesar 1,509 berada di antara -2 dan +2 sehingga tidak ada autokorelasi dan dapat disimpulkan bahwa untuk uji Autokorelasi telah terpenuhi.

\section{E. Persamaan Regresi Berganda}

\section{Tabel 4. Regresi Berganda}

\begin{tabular}{|c|c|c|c|c|c|c|}
\hline \multicolumn{7}{|c|}{ Coefficients ${ }^{\circ}$} \\
\hline \multirow{2}{*}{\multicolumn{2}{|c|}{ Model }} & \multicolumn{2}{|c|}{ Unstandardized Coefficients } & \multirow{2}{*}{$\begin{array}{c}\text { Standardized } \\
\text { Coefficients } \\
\text { Bota } \\
\end{array}$} & \multirow[b]{2}{*}{$t$} & \multirow[b]{2}{*}{ Sig. } \\
\hline & & B & Std. Error & & & \\
\hline \multirow[t]{3}{*}{1} & (Constant) &, 043 & 4,586 & &, 009 & ,993 \\
\hline & Citra Toko $\left(X_{1}\right)$ &, 124 &, 158 &, 180 &, 783 &, 438 \\
\hline & Atmosfer Toko $\left(X_{2}\right)$ & 444 & 204 & 499 & 2,175 & 036 \\
\hline
\end{tabular}

a. Dependent Variable: Keputusan Pembelian ( $Y$ )

Sumber: Data SPSS

$Y=0,043+0,124 X_{1}+0,444 X_{2}+\epsilon$

Dari persamaan di atas menunjuk pengertian sebagai berikut:

1) Nilai konstanta sebesar 0,043 artinya menunjukkan bahwa nilai murni keputusan pembelian tanpa dipengaruhi citra toko dan atmosfer toko.

2) Nilai regresi $X_{1}$, citra toko sebesar 0,124 artinya citra toko mengalami kenaikan sebesar satu-satuan maka keputusan pembelian mengalami kenaikan sebesar 0,124.

3) Nilai regresi $X_{2}$, atmosfer toko sebesar 0,444 artinya image toko mengalami kenaikan sebesar satu-satuan maka keputusan pembelian mengalami kenaikan sebesar 0,444.

Dengan membandingkan semua koefisien regresi pada $\mathrm{X} 1$ dan $\mathrm{X} 2$ terlihat bahwa koefisien X2, atmosfer toko lebih besar dibanding koefisien $\mathrm{X} 1$, citra toko. Ini berarti setiap ada peningkatan pada variabel atmosfer toko sangat mempengaruhi keputusan pembelian konsumen. 


\section{F. Uji t}

\section{Tabel 5: Uji t}

\begin{tabular}{|c|c|c|c|c|c|c|}
\hline \multicolumn{7}{|c|}{ Coefficients $^{\circ}$} \\
\hline \multirow{2}{*}{\multicolumn{2}{|c|}{ Model }} & \multicolumn{2}{|c|}{ Unstandardized Coefficients } & \multirow{2}{*}{$\begin{array}{c}\text { Standardized } \\
\text { Coefficients } \\
\text { Beta }\end{array}$} & \multirow[b]{2}{*}{$\mathrm{t}$} & \multirow[b]{2}{*}{ Sig. } \\
\hline & & B & Std. Error & & & \\
\hline 1 & (Constant) & 043 & 4,586 & & 009 & 993 \\
\hline & Citra Toko $(X 1)$ &, 124 &, 158 & .180 & .783 & 438 \\
\hline & Atmosfer Toko (X2) & 444 & 204 & 499 & 2,175 & 036 \\
\hline
\end{tabular}

a. Dependent Variable: Keputusan Pembelian (Y)

\section{Sumber: Data SPSS}

Hasil perhitungan diketahui sebagai berikut:

\section{$\mathrm{X}_{1}$, citra toko}

1) thitung $<t_{\text {tabel }}$ atau $0,783<2,052$ maka $\mathrm{HO}$ ditolak dan $\mathrm{H} 1$ diterima artinya variabel bebas tidak berpengaruh terhadap variabel terikat.

2) Nilai signifikasi $>0.05$ atau 0,438 $>0,05$ maka variabel bebas tidak berpengaruh signifikan terhadap variabel terikat.

Kesimpulan perhitungan di atas menunjukkan bahwa variabel $\mathrm{X}_{1}$, citra toko tidak berpengaruh signifikan terhadap keputusan pembelian konsumen.

\section{$\mathrm{X}_{2}$, atmosfer toko}

1) thitung $<$ tabel atau 2,175 $>2,026$ maka $\mathrm{H} 0$ diterima dan $\mathrm{H} 1$ ditolak artinya variabel bebas berpengaruh terhadap variabel terikat.

2) Nilai signifikasi $<0.05$ atau 0,036 $<0,05$ maka variabel bebas berpengaruh signifikan terhadap variabel terikat.

Kesimpulan perhitungan di atas menunjukkan bahwa variabel $X_{2}$, atmosfer toko berpengaruh signifikan terhadap keputusan pembelian konsumen. 


\section{G. Uji F}

Tabel 6: Uji F

ANOVA

\begin{tabular}{|c|c|c|c|c|c|c|}
\hline \multicolumn{2}{|c|}{ Model } & Sum of Squares & df & Mean Square & $\mathrm{F}$ & Sig. \\
\hline \multirow[t]{3}{*}{1} & Regression & 322,472 & 2 & 161,236 & 14,127 & $.000^{\circ}$ \\
\hline & Residual & 422,303 & 37 & 11,414 & & \\
\hline & Total & 744,775 & 39 & & & \\
\hline
\end{tabular}

a. Dependent Variable: Keputusan Pembelian (Y)

b. Predictors: (Constant), Atmosfer Toko (X2), Citra Toko (X1)

Sumber: Data SPSS

Pengujian variabel bebas $\mathrm{X}$ secara bersama-sama terhadap variabel $Y$ dilakukan uji $F$ dimana $F_{\text {tabel }}=3,25$ dan $F_{\text {hitung }}=14,127$. Hasil perhitungan diketahui:

1) $F_{\text {hitung }}>\mathrm{F}_{\text {tabel }}$ atau 14,127 $>3,25$ maka $\mathrm{HO}$ ditolak dan $\mathrm{H} 1$ diterima, artinya ada pengaruh secara simultan

2) Jika sig $<\alpha(0.05)$, atau $0,000<0,05$ maka $\mathrm{H} 0$ ditolak dan $\mathrm{H} 1$ diterima

Arti dari dua perhitungan tersebut menunjukkan variabel $X_{1}$, citra toko dan $\mathrm{X}_{2}$, atmosfer toko bersama-sama mempengaruhi keputusan pembelian konsumen.

\section{H. Koefisien Korelasi Parsial}

Tabel 7: Koefisien Korelasi Parsial Correlations

\begin{tabular}{|c|c|c|c|c|}
\hline & & Citra Toko (X1) & $\begin{array}{l}\text { Atmoster Toko } \\
\left(X_{2}\right) \\
\end{array}$ & $\begin{array}{c}\text { Keputusan } \\
\text { Pembelian (Y) }\end{array}$ \\
\hline \multirow[t]{3}{*}{ Citral Toko $\left(X_{1}\right)$} & Pearson Correlation & 1 & $.842^{-1}$ & $.600^{-}$ \\
\hline & Sig. (2-tailed) & &, 000 &, 000 \\
\hline & $\mathrm{N}$ & 40 & 40 & 40 \\
\hline \multirow[t]{3}{*}{ Atmoster Toko $(X 2)$. } & Pearson Corretation & $842^{-\prime}$ & 1 & $651^{-}$ \\
\hline & Sig. (2-tailed) & .000 & & .000 \\
\hline & $\mathrm{N}$ & 40 & 40 & 40 \\
\hline \multirow[t]{3}{*}{ Keputusan Pembelian $(Y$ ) } & Pearson Correlation & $600^{-}$ & $651^{-}$ & 1 \\
\hline & Sig (2-tailed) & .000 & .000 & \\
\hline & $\mathrm{N}$ & 40 & 40 & 40 \\
\hline
\end{tabular}

$*$. Corretation is significant at the 0.01 level (2-tailed).

Sumber: Data SPSS 
Berdasarkan dari tabel di atas dan list mutlak korelasi di bawah ini:

\begin{tabular}{|c|c|}
\hline Nilai Mutlak Korelasi & Tingkat Keeratan \\
\hline $0,00-0,199$ & Sangat rendah \\
$0,20-0,399$ & Rendah \\
$0,40-0,599$ & Sedang \\
$0,60-0,799$ & Erat \\
$0,80-1,000$ & Sangat erat \\
\hline
\end{tabular}

1) Dari hasil uji koefisien korelasi antara citra toko terhadap keputusan pembelian sebesar $0,600^{* *}$ artinya citra toko terhadap keputusan pembelian mempunyai hubungan yang erat dan positif.

2) Dari hasil uji koefisien korelasi antara atmosfer toko terhadap keputusan pembelian sebesar $0,651^{* *}$ artinya atmosfer toko terhadap keputusan pembelian mempunyai hubungan yang erat dan positif.

Kesimpulan dari data di atas menunjukkan bahwa ke dua citra toko dan atmosfer toko sama-sama mempunya hubungan yang erat dan positif terhadap keputusan pembelian konsumen.

\section{Koefisien Korelasi Berganda}

Tabel 7. Koefisien Korelasi Berganda

Model Summaryb

\begin{tabular}{|l|r|r|r|c|}
\hline Model & R & R Square & \multicolumn{1}{c|}{$\begin{array}{c}\text { Adjusted R } \\
\text { Square }\end{array}$} & $\begin{array}{c}\text { Std. Error of the } \\
\text { Estimate }\end{array}$ \\
\hline 1 &, $658^{\mathrm{a}}$ &, 433 & 0,402 & 3,378 \\
\hline
\end{tabular}

a. Predictors: (Constant), Atmosfer Toko (X2, Citra Toko (X1)

b. Dependent Variable: Keputusan Pembelian (Y)

Sumber: Data SPSS 
Berdasarkan dari tabel di atas dan list mutlak korelasi ditarik kesimpulan bahwa koefisien korelasi berganda (R) adalah sebesar 0,658 yang berarti mempunyai hubungan erat dan positif diantara antara variabelvariabel $X_{1}$, citra toko dan $X_{2}$, atmosfer toko terhadap keputusan pembelian konsumen $(\mathrm{Y})$.

Koefisien Determinasi ganda (Adjusted $R^{2}$ ) sebesar 0,433 menunjukkan bahwa keputusan pembelian konsumen di pengaruhi oleh variabel-variabel $X_{1}$, citra toko dan $X_{2}$, atmosfer toko sebesar $43,30 \%$ sedangkan 56,70 \% dipengaruhi oleh faktor-faktor lain yang tidak dimasukkan ke dalam variabel-variabel penelitian.

\section{PENUTUP}

\subsection{Kesimpulan}

Berdasarkan hasil penelitian mengenai citra toko dan atmosfer toko terhadap keputusan pembelian konsumen di Ramayana Depok maka dapat disimpulkan sebagai berikut:

1) Berdasarkan penelitian menunjukkan variabel $X_{1}$, citra toko tidak berpengaruh signifikan terhadap keputusan pembelian konsumen di Ramayana Depok. Dibuktikan dengan nilai probabilitas $>0,05$. Ramayana Depok perlu melakukan evaluasi atas kesan pelanggan baik secara internal (desain, layout, kebersihan dan keamanan toko) dan eksternal (fisik toko) yaitu fisik toko yang mempengaruhi citra toko Ramayana Depok

2) Berdasarkan penelitian menunjukkan variabel $X_{2}$, atmosfer berpengaruh signifikan terhadap keputusan pembelian konsumen di Ramayana Depok. Dibuktikan dengan nilai probabilitas $<0,05$. Hal ini sesuai dengan visi dan misi perusahaan dimana Ramayana Depok adalah satu toko yang mengalami transformasi toko yaitu menjadi toko prime yaitu perubahan desain dan tampilan gerai sehingga menjadi tempat berbelanja yang lengkap dan menawarkan produk-produk 
fashion bermerek. Perubahan toko Ramayana Depok menjadi toko prime karena ingin membidik segmen pasar baru yaitu kaum milenial (annual report 2018-2019)

3) Berdasarkan penelitian menunjukkan secara simultan menunjukkan variabel $X_{1}$, citra toko dan $X_{2}$, atmosfer toko bersama-sama berpengaruh signifikan dan positif terhadap keputusan pembelian konsumen di Ramayana Depok. Dibuktikan dengan nilai probabilitas $<0,05$. Hasil ini mendukung dari hasil penelitian lain yang dilakukan oleh Ristyana (2015) bahwa secara simultan citra toko dan atmosfer toko mempengaruhi keputusan pembelian.

4) Berdasarkan penelitian menunjukkan bahwa keputusan pembelian konsumen di pengaruhi oleh variabel-variabel $\mathrm{X}_{1}$, citra toko dan $\mathrm{X}_{2}$, atmosfer toko sebesar $43,30 \%$ sedangkan $56,70 \%$ dipengaruhi oleh faktor-faktor lain. Salah satu faktor adalah strategi pemasaran mengedepankan konsep barang dengan harga murah dengan iklan di Youtube dengan penonton sebanyak 16 juta penonton, endorsemen artis yang sesuai karakter Ramayana, kerja sama dengan e-comerce (Lazada) dan promosi diskon yang diterapkan oleh Ramayana yaitu hingga 70 \% (https://lifepal.co.id/media/ramayana-store-dan-strategi-)

\subsection{Saran}

1) Beberapa metode yang dapat dilakukan oleh untuk Ramayana Depok di dalam meningkatkan penjualan:

a) Melakukan Mystery Shooping atau Ghost Shooping untuk mengukur tingkat pelayanan, ketersediaan merchandise, kondisi toko, promosi yang dilakukan apakah sudah sesuai dengan keinginan pelanggan.

b) Melakukan survei kepuasan pelanggan untuk mendapatkan informasi-informasi dari konsumen yang dapat dijadikan suatu masukan sebagai bahan perbaikan toko untuk meningkatkan penjualan Ramayana Depok. 
2) Meningkatkan strategi pemasaran online yang sudah berjalan (Tokokpedia, Shopee dan Lazada dengan beberapa marketplace lain seperti Bukalapak, Blibli, Zalora, JD.id dan orami yang merupakan marketplace yang memiliki pengunjung terbaca di Indonesia (https://sasanadigital)

\section{DAFTAR PUSTAKA}

Cut Devi, Damrus, Pengaruh Bauran Pemasaran Eceran Terhadap Keputusan pembelian Konsumen Pada Indomaret Lueng Bata Banda Aceh, Fakultas Ekonomi Universitas Tengku Umar, Vol 4 No 12020

Christina Whidya Utami, Manajemen Retail, Edisi 3, Salemba Empat, 2010

Ghozali, Imam, Aplikasi Analisis Multivariate Dengan Program SPSS, Semarang, UNDIP, 2005

Ma'ruf, Hendri, Pemasaran Ritel, Cetakan 1, Penerbit PT. Gramedia Pustaka Utama, Jakarta, 2005

Muhammad Rifa'l, Pengaruh Citra Toko Terhadap Niat beli Konsumen Pada Minimarket Alfamart Bandar Lampung, Fakultas Ekonomi dan Bisnis, Universitas Bandar Lampung 2018

Maftukhan, Muhammad, Shopping Lifestyle dan Store Enviroment Pengaruhnya Terhadap Keputusan Pembelian Baju Cosmic di Surabaya, Universitas PGRI Adi Buana Majalah Ekonomi_ISSN No 1411 - 9501 Volume XXII No 2 Desember 2017

Simamora, Bilson, Membongkar Kotak Hitam Konsumen, Penerbit PT. Gramedia Pustaka Utama, Jakarta, 2003

Sugiarto, Dergibson Siagian, Lasmono Tri Sunaryanto, Teknik Sampling,

PT. Gramedia Pustaka Utama, Cetakan 2, Agustus 2003

Sugiyono, Statistik Untuk Penelitian, Bandung, alfabeta, tahun 2009

Sugiyono, Metode Penelitian Kuantitatif dan RD Bandung, Alfabeta tahun 2012

Kholid Akbar, Pengaruh Retail Mix Terhadap Keputusan Pembelian Pada Sarikat Jaya Swalayan Gresik, Jurnal perbankan Syariah dan Ekonomi Syariah, Vol 02 No. 01, Mei 2020

Kotler, Philip dan Kevin Lane Keller, Manajemen Pemasaran, Jakarta: Erlangga, 2009 
Krumpellman Luis, MSc - Thesis "The Influence of Store Environment on Customers' Satisfaction and Purchasing Behaviour", University of Wageningen, Jermany 2018

Ristyana dkk, Pengaruh Store Image dan Store Atmosphere Terhadap Impulse Buying (Study Kasus konsumen Robinson Department Store Mall Ciputra Semarang, Jurnal Ilmu Administrasi Bisnis, Vol 4 No 3 2015

Venty Septian T, Achamd Fauzi, M. Kholid Mawardi," Jurnal Pengaruh Store Atmosphere Terhadap Emosi Serta Dampaknya Pada Keputusan pembelian (Survey Pada Pembelian di Ria Djenaka Café dan Resto, Kota Batu Malang)", Universitas Brawijaya Malang 2016

https://databoks.katadata.co.id/datapublish/2019/04/29/jumlah-penduduk indonesia-269-juta-jiwa-terbesar-keempat-dunia

https://ekonomi.bisnis.com/read/20190107/12/876089/2019-bisnis-ritelmodern-ditarget-tumbuh-10

https://fokus.tempo.co/read/1005342/bisnis-online-kuasai-18-persenpasar-ritel

https://www.ceicdata.com/id/indicator/indonesia/retail-sales-growth

https://www.cnnindonesia.com/ekonomi/20171107113943-92-

254005/gesernya-pola-konsumsi-dan-biang-keladi-lesunya-ekonomi?

https://sasanadigital.com/pilih-marketplace-atau-toko-online-sendiripahami-dulu-perbedaannya/

https://www.mataharimall.com.

http://www.ramayana.co.id/ 